RESENA

\title{
Guillermo Muñoz Rivas
}

\author{
Jorge Raad, Carlos A. Hernández
}

Guillermo Muñoz Rivas nació en Chocontá el 30 de julio de 1908; obtuvo su grado de bachillerato en 1926 en la primera promoción en ciencias naturales del Liceo de La Salle. Inmediatamente después, en 1927 y 1928, asistió a los cursos de bacteriología, histología, parasitología, fisiología y química biológica de la Facultad de Medicina de Bogotá.

El 15 de febrero de 1929 recibió el certificado de idoneidad para practicar exámenes de laboratorio clínico de manos de don Antonio Peña Chavarría, director del Laboratorio Samper Martínez, el cual fue ratificado por don Pablo García Medina, Director Nacional de Higiene y Asistencia Pública. Durante este año, también se desempeñó como ayudante técnico del profesor Marshall Hertig en la primera campaña antipalúdica de Colombia.

Durante 1930 y 1931, hizo estudios de entomología, bacteriología, botánica e inmunidad en el Kaiser Wilhem Universitat de Berlín y cursos de medicina tropical, protozoología, helmintología, bacteriología, química biológica y anatomía patológica en el Tropeninstitut de Hamburgo. Allí recibió la certificación de haber completado exitosamente los cursos de tales disciplinas al lado de profesores de la talla de Reichenow, Enderlein, Martini, Fulleborn, Mayer, Giemsa, Nauck y Haim. De regreso a Colombia, visitó el Instituto Pasteur y el Instituto Profiláctico en París y algunos laboratorios particulares; además, permaneció un mes con Marshall Hertig en la Universidad de Harvard.

Al regresar a Colombia, en 1932, obtuvo su licenciatura en bacteriología y química biológica otorgada por el Departamento Nacional de Higiene, Sección de Estadística Vital. Ese mismo año, el doctor Reinaldo Arango Vélez creó el Laboratorio Municipal de Higiene de Bogotá, y lo nombró como jefe.

En 1933, se casó con Leonor Vila Escobar. Durante cuarenta años ejerció el trabajo de laboratorista clínico privado en donde se distinguió por su acreditación académica, lo que le permitió una importante labor asistencial. Posteriormente, regresó a sus trabajos de microbiología en especial a los de lepra, los cuales realizó durante 42 años.

De 1939 a 1944, fue jefe de la Sección de Microbiología del Instituto Federico Lleras Acosta, cargo al cual renunció por diferencias de opinión en la orientación que debía tener el instituto.

La cátedra fue uno de sus pilares laborales tanto en el Colegio de San Simón en Ibagué y en el Colegio Mayor Departamental de La Merced en Bogotá, como en la Facultad de

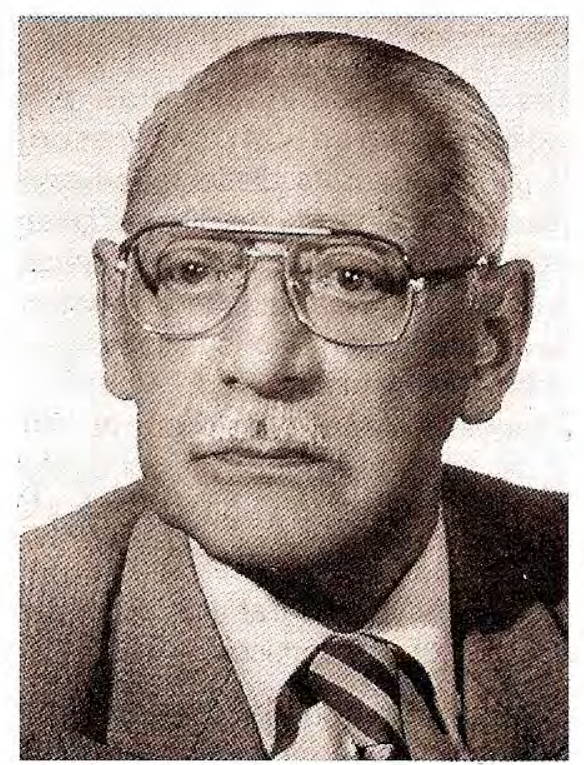


Medicina de Bogotá, la Facultad de Medicina y de Farmacia de la Universidad Nacional -fue auxiliar del profesor César Uribe Piedrahita-, en el Colegio Mayor de Cundinamarca y, al jubilarse, fue nombrado decano asociado de la Escuela de Medicina Juan N. Corpas. Dictó varias asignaturas de las cuales hacía gala de profundos conocimientos $y$, sobre todo, experiencia infinita en los campos de la bacteriología, la parasitología y la microbiología, con especial énfasis en las micobacterias.

Ingresó al Instituto Nacional de Salud como jefe de la Subdivisión de Investigaciones Epidemiológicas a partir de 1961, y de 1962 a 1980 condujo la Sección de Lepra del mismo instituto en donde se distinguió por sus trabajos en el orden nacional e internacional. En 1974, creó el laboratorio de campo en San Gil por convenio entre el INPES y el Hospital San Juan de Dios.

Fue miembro de innumerables sociedades científicas, entre las que se distinguen la Academia Nacional de Medicina tanto en su calidad de miembro de número y, luego, honorario; miembro de número de la Academia Colombiana de Ciencias; miembro de número de la Sociedad Colombiana de Leprología; la Academia de Medicina de Medellín, la Real Academia de Ciencias de Madrid y otras relacionadas con la microbiología y el laboratorio clínico.

Múltiples congresos nacionales e internacionales contaron con su presencia y trabajos. Recibió varias distinciones entre las que se destacan el premio sobre etiopatogenia de la lepra de la Academia de Rio de Janeiro en 1947, la Medalla Cívica del Mérito Asistencial y Sanitario Jorge Bejarano por sus investigaciones en lepra en 1966 y el doctorado Honoris causa de la Escuela de Medicina Juan N. Corpas. Durante 16 años fue miembro del Comité de Expertos en Lepra de la Organización Mundial de la Salud.

La bibliografía refiere 52 trabajos publicados en diferentes medios académicos.

Uno de sus intereses fue la filmación y produjo ocho documentales sobre variados tópicos de la microbiología, la parasitología y la herpetología; uno de ellos, La agonía de la lepra, está considerado como tesoro nacional.

Mas la vida del profesor Muñoz Rivas, tuvo ribetes muy diversos en su trasegar por las largas ocho décadas; su independencia de espíritu frente a su casa paterna fue el comienzo de una estructuración interna fuerte que incluyó una posición personalísima frente a la iglesia católica, a diferencia de la gran mayoría de personalidades de la época.

El cultivo del arte, tanto en la música como en su propia expresión pictórica, fueron bastiones para prolongar una vivencia interna de contornos contradictorios entre su carácter y la dulzura del arte. En 1969, recibió el primer premio del Salón Panamericano de Médicos Artistas dentro del XI Congreso Latinoamericano de Cirugía Plástica con su cuadro Calitecnia \#1, nombre que le dió López de Mesa a la técnica empleada por Muñoz Rivas, que significa la técnica al servicio de la belleza.

La personalidad atrayente, dominante e hiperactiva fueron siempre su compañía e incansables motores en sus desplazamientos continuos en busca de confrontar y validar sus convicciones científicas.

Los hombres viven, pero cuando lo hacen entendiendo y expresando sus propias cualidades de una manera inconsciente, son una verdadera maravilla al servicio de los demás, así vivió la vida el maestro Muñoz Rivas. La delicadeza de su espíritu se reflejó en su querencia a las rosas que fueron incomparables compañeras en su momentos de soledad y alegría. Falleció el 1 de febrero de 1989.

Guillermo Muñoz Rivas, aunque no fue médico, entendió -como lo hacen los sabios- el poder de la biología y la fuerza de sus leyes. Su figura y su obra son pilares del trabajo del instituto en un campo en el cual ha cooperado a su control: la lepra.

\section{Referencias}

Muñoz P. Hoja de vida de Guilllermo Muñoz Rivas. Academia Nacional de Medicina; 1994. 